\title{
Hermeneutics of Ikat Weaving (Utan) Lian Lipa from Sikka Regency, East Nusa Tenggara (NTT)
}

\author{
Leonard Davinci Elain Koten¹, Reza Safitri², Maulina Pia Wulandari ${ }^{3}$ \\ 1,2,3Brawijaya University, Malang, Indonesia \\ Email: leonard davinci@student.ub.ac.id
}

\begin{abstract}
Indonesia is famous for the amazing diversity of woven fabrics, so it has a special place in the hearts of its people. This diversity of woven fabrics is also owned by the people of Sikka Regency, East Nusa Tenggara (NTT) Province. The type of woven fabric that is well-known in the Sikka Regency area is ikat woven fabric (Tallo, 2003). In general, the ikat woven fabrics of Sikka Regency can be distinguished based on gender, namely the women's woven ikat cloth which in Sikka-Krowe language is called utan and the male woven ikat cloth called ragi or lipa. One of the women's ikat cloth (utan) originating from Sikka Regency, namely the Lian Lipa utan. However, the existence of the Lian Lipa utan is still unknown to some people in Sikka Regency, especially related to symbols, such as the motifs on the woven cloth. Apart from symbols, other factors such as norms, social status, traditions and community beliefs attached to this forest are also not widely known. Thus, an in-depth study is needed to be able to answer the overall symbolic meaning of the Lian Lipa utan, namely through a hermeneutic phenomenological approach. Thus, this study aims to determine the hermeneutics of the woven ikat (utan) Lian Lipa. The research methodology used is a qualitative method and the data collection techniques are observation, in-depth interviews and document studies. Through a hermeneutic phenomenological approach by using the Symbolic Interaction Theory of George Herbert Mead and Herbert Blumer, the results of his research show that the hermeneutics of the ikat cloth motif basically comes from the mindset and process of social interaction that has taken place since ancient times.
\end{abstract}

Keywords: Phenomenological Studies, Hermeneutics, Lian Lipa Woven Fabric, Sikka Regency.

\section{A. INTRODUCTION}

Indonesia is famous for the amazing diversity of woven fabrics, so it has a special place in the hearts of its people. This is what causes Indonesian woven fabrics to be used as one of the best woven fabrics in the world, especially in terms of the diversity of decorative patterns that can be seen in terms of colors, motifs, quality of materials and threads used (Edie, 2011). This diversity of woven fabrics is also owned by the people of Sikka Regency, East Nusa Tenggara Province (NTT) which are inherited from each generation. The type of woven fabric that is wellknown in the Sikka Regency area is ikat woven fabric (Tallo, 2003).

In general, the ikat woven fabrics of Sikka Regency can be distinguished based on gender, namely the women's woven ikat cloth which in Sikka-Krowe language is called utan and the male woven ikat cloth called ragi or lipa. One of the women's ikat cloth (utan) originating from Sikka Regency, namely the Lian Lipa utan. However, the existence of the Lian Lipa utan is still unknown to some people in Sikka Regency, especially related to symbols, such as the motifs on the woven cloth. Apart from symbols, other factors such as norms, social status, traditions and 
community beliefs attached to these utan are also not widely known. Thus, an indepth study is needed to be able to answer the overall symbolic meaning of the Lian Lipa utan.

Each woven fabric has a characteristic that is closely related to the culture of the local area. Culture is the result of human creativity that continues to develop from the process of interaction and communication with the outside world. The process of interaction and communication that occurs will involve all people from various socio-cultural backgrounds, resulting in different understandings (Aw, 2010). On the other hand, communication is also a ceremonial process that requires our participation in managing, preserving and changing culture (Subtil, 2014). Culture is not only cults and customs, but also a structure of meaning that shapes values and experiences (Geertz, 1992). The existence of a good communication process between one generation and another will make it easier to preserve the existing culture.

Culture is believed to be a supporting framework system that combines selfbeliefs, values, norms, traditions and communication patterns as a way of organizing, offering certain groups a view of the world that allows each individual to understand it (Barker, 2016). This is because the relationship between culture and communication is so close that it is like two sides of a coin (Kuswarno, 2009). In fact, Anthropologist Edward T. Hall (quoted in Mulyana, 2011), argues that culture is communication and communication is culture. According to Hall, culture and communication have a reciprocal relationship or in other words, when we "learn" culture through communication, at the same time communication is also a reflection of culture itself (Samovar et al., 2014).

The world of culture is a world full of symbols and humans live in that symbolic world. One of the basic human needs, as stated by Susanne K. Langer (quoted in Mulyana, 2005) is the need for symbolization or the use of symbols. Humans are the only animals that use symbols and that is what distinguishes humans from other creatures. So, it is not without reason that Ernst Cassirer (18741045) tends to mark humans as animal symbolicum because they have advantages and privileges from other living creatures (Mulyana, 2005). Humans think, feel and act in symbolic expressions, such as language, myth, art, culture, religion are part of the symbolic world. As a result of the symbolization process, it causes multiple interpretations of each object. For example, in every ikat cloth object, there are usually motifs and other elements that complement each other. The motifs and other elements that complement each other should be interpreted to find out the symbolic meaning contained in each of the ikat cloths. The process of interpreting each communication activity is only possible in the study of Communication Science, through a phenomenological study approach, specifically a hermeneutic phenomenological study based on the perspective of symbolic interaction theory. 


\section{B. LITERATURE REVIEW}

\section{Phenomenological Approach}

Phenomenology is the study of phenomena and their nature and meaning (Finlay, 2009). The focus is to provide a description or interpretation of everything that appears through the life experiences of a person or group of people (Kafle, 2011). Furthermore, (Kafle, 2011) divides the study of phenomenology into 3 parts, namely transcendental phenomenology, existential phenomenology and hermeneutic phenomenology. Transcendental phenomenology is the original form of philosophical studies which is the root of phenomenological studies as conceptualized by Edmund Husserl (1859-1938). Existential phenomenology focuses on the individual level of culture which includes the internalization of the subjective consciousness of the individual. For the study of hermeneutic phenomenology, it focuses on the collective aspects of culture that are concerned with language, so that texts can be analyzed objectively, in the sense of exploring and determining the nature and structure of communication.

\section{Hermeneutic Phenomenology}

Like the study of phenomenology in general, hermeneutic phenomenology is also related to the world of life or life experiences lived by humans. The focus is on describing in detail the life aspects of any experience that can be taken for granted in our lives, with the aim of creating meaning and achieving a common sense of understanding (Wilson \& Hutchinson, 1991). The meaning of description as a method of hermeneutic phenomenology lies in interpretation. Interpretation is not an additional procedure, but rather as an inescapable basic structure of "our existence in the world" (Finlay, 2012).

Referring to the understanding of the hermeneutic phenomenological study which states that every object always contains a hidden meaning that must be interpreted in the form of a text and the text itself contains meaning, the interpretation process is to reveal the meaning that is still implied and hidden in the text. Thus, related to the meaning of the symbols of the woven cloth motifs, the study of hermeneutic phenomenology is understood as a study to interpret the meaning of various works of art (woven fabric motifs) using language in the form of text. Therefore, the Sikka-NTT Regency ikat motif was chosen as an object that can be interpreted, because of the symbolic meaning contained in each of the woven ikat fabrics. Thus, the motifs on each of the ikat cloths are also a "text" which is full of symbolic meanings to be interpreted.

The link between culture and the study of hermeneutic phenomenology is emphasized by Geertz (2017), that culture is an active dimension of social life and is more than just a guarantee mechanism for social integration. Culture is also understood as a very complex network of signs, symbols, myths, routines and habits that need to be described in a thick description. Furthermore, Geertz said that culture is not only a pattern of visible behavior, but culture has an interpretive nature, as a "semiotic" concept and as a "text". Because culture is a semiotic concept 
and as a text, the cultural product must be read, translated and interpreted in order to know the meaning contained in it (Kuper, 1999).

\section{Symbolic Interaction Theory}

Symbolic Interaction Theory was originally proposed by George Herbert Mead (1863-1931). After that, Herbert Blumer (1900-1987) who was a student of Mead, continued Mead's ideas by combining many works whose ideas are the main foundation in symbolic interaction (Burbank and Martins, 2009).

There are 3 premises of the Symbolic Interaction Theory, namely (1) humans act on things based on the meanings that something has for them, (2) these meanings come from the process of social interaction that a person has with other people, (3) the meaning is modified and then analyzed through an interpretation process and refined during the social interaction process (Carter \& Fuller, 2016). Symbolic Interaction Theory understands certain interactions that occur in certain contexts (Dennis, 2011). Symbols, especially words, are central concepts from the perspective of Symbolic Interaction Theory (Burbank and Martins, 2009). Symbols are created socially and are used to represent shared meanings among members or groups of people in the cultural world.

Denzin (2016), explains that the term symbolic in the phrase symbolic interaction refers to the geographical foundation that underlies the life of human groups. The word interaction refers to the fact that people do not act on one another, but interact with one another. By using the term interaction, Symbolic Interaction Theory is committed to studying and analyzing developmental actions that occur when two or more people combine their individual actions into joint action. Symbolic interaction focuses on the interpretation of the meaning of each symbol and an understanding of the reality of life from each individual subjectively (Carter and Fuller, 2016).

\section{METHOD}

The location of the research on the hermeneutics of Lian Lipa's ikat cloth (utan) is located at Sanggar Ikat Weaving Bliran Sina, Kajowair Village, Hewokloang District, Sikka Regency, East Nusa Tenggara Province (NTT). The focus of the research in this study is to understand the hermeneutics of Lian Lipa's woven ikat cloth (utan) by interpreting the motifs and various elements contained in them.

This study used qualitative research methods. Researchers will explore complete and detailed information related to Lian Lipa's hermeneutics of woven ikat cloth (utan) by carrying out several stages, such as observations, interviews and literature studies. In this study, researchers used a phenomenological approach, especially hermeneutic phenomenology. In general, phenomenology is the study of how humans as subjects interpret the objects around them. However, there are important differences that are clearly visible from the research methodology between the general phenomenological approach and hermeneutic phenomenology. According to Kvale, Osborne \& Polkinghorne (quoted in Laverty, 2003), the 
methodology of the phenomenological approach is generally descriptive and focuses on the structure of experience, the organizing principles that give form and meaning to the world of life. Meanwhile, the methodology with a hermeneutic phenomenology approach according to Barclay \& Polkinghorne (quoted in Laverty, 2003), is interpretive and concentrated on the meaning of historical experience and the influence of its cumulative development at the individual and social levels. This process of interpretation or interpretation includes collectively explicit statements about the meaning of historical experience. Furthermore, Laverty (2003), explains that the hermeneutic phenomenological approach asks researchers to engage in a process of self-reflection with a very different purpose from the phenomenological approach. In particular, the researcher's biases and assumptions are not confined or sidelined, but are embedded and important to the interpretation process.

Although there are differences between the phenomenological approach in general and hermeneutic phenomenology, according to Ricoeur (quoted in Driyanti, 2011), the hermeneutic phenomenological approach cannot be separated from phenomenology in general. Phenomenology is an irreplaceable basic assumption for hermeneutics. Phenomenology cannot run its program to understand various phenomena completely and thoroughly without an interpretation process. For the purposes of the interpretation process, a hermeneutic phenomenological approach is needed. So, basically, the hermeneutic phenomenological approach and the general phenomenological approach are complementary.

To determine the informants in this study, the researchers chose informants from parties directly involved in the activity of making woven ikat fabrics. Determination of the informants selected by purposive sampling. The informants were selected on the basis of certain criteria made by the researcher based on the research objectives (Kriyantono, 2014). In this case, the researcher chose informants from people who use woven ikat products, either in the form of sarongs, clothes, skirts or in the form of other accessories. In addition, the determination of informants can also be done by snowball sampling which usually grows more and more according to the needs in the field. In this case, the researchers selected informants from ikat weaving culture activists, both owners of weaving groups and owners of weaving studios in the Sikka-NTT Regency area, as well as local community leaders, cultural experts, academics who are still consistent in exploring and continuing the weaving tradition.

Based on the technique of determining informants by purposive sampling and snowball sampling, the researchers finally selected 8 informants, both male and female. The researcher hopes that the selected informants will be able to provide comprehensive information, explanations, suggestions, suggestions as sources of accurate data in accordance with the formulation of the problem and the objectives of this study. Creswell (1998), explains that data collection techniques in qualitative research through a phenomenological study approach are observation, in-depth interviews and the study of official documents. In this study, researchers conducted in-depth interviews related to the symbolic meaning of woven ikat motifs and made 
observations or observations on the community owners of weaving groups and weaving studios. The data obtained from the results of in-depth interviews and observations were then summarized and reduced. After that, the data related to the symbolic meaning of the ikat cloth motifs are interpreted by the symbolic meaning of the motifs contained in each ikat cloth which is then analyzed and described in the form of text.

According to Miles \& Huberman (2009), there are several stages in the data analysis technique used in this study, namely data reduction, data display, conclusion and verification. The data validity technique is a technique used to test the level of validity of the data used in qualitative research (Kriyantono, 2014). This is to prevent errors in the data that has been collected, so researchers need to check the validity of the data. Data validity techniques can be carried out in 3 ways, namely adding or extending research observation time, increasing persistence and triangulation.

\section{RESULT AND DISCUSSION}

The woven ikat (utan) Lian Lipa is also known as the Nian Nepa. The name Nian Nepa comes from the Sikka-Krowe language, namely from the word nian which means island and the word nepa (nipa) which means snake. However, the majority of ethnic groups in Sikka Regency call him Lian Lipa. When translated literally, this ikat cloth is interpreted as the island of snakes which is a representation of the island of Flores which is shaped like a snake. Nian Nepa or Lian Lipa is a special woven cloth for women which in Sikka-Krowe language is called utan. So, the people of Sikka-NTT district usually call it the Lian Lipa or Nian Nepa.

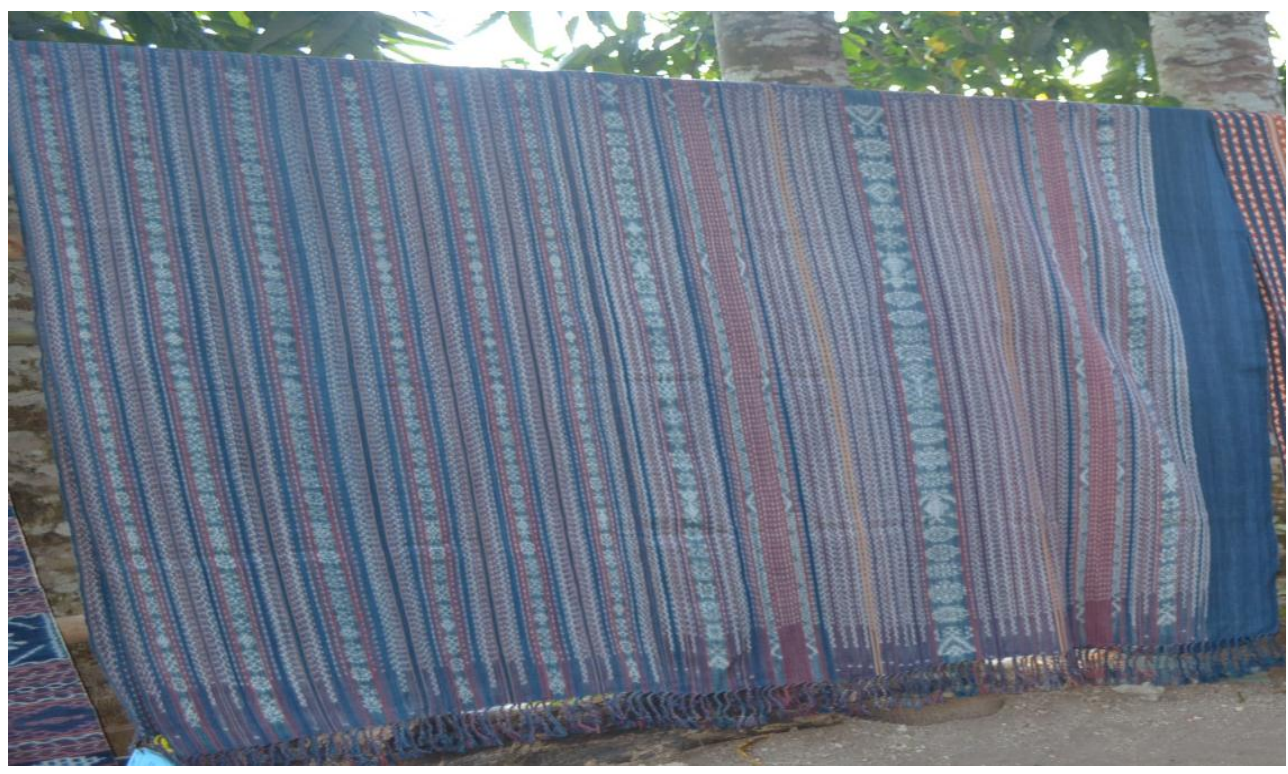

Figure 1: Utan Lian Lipa or Nian Nepa

(Data Processed by Researchers, 2020)

Although it literally means snake island, the motifs on Lian Lipa's do not come from snakes, but come from a combination of geckos, dragon skin, pineapple 
fruit shoots and objects such as plates, jars and bahar tibu (gold). The gecko is the main motif and is flanked by dragon skin, pineapple shoots, plates, jars and bahar tibu as complementary motifs. The gecko is a four-legged reptile, hard-skinned, has a loud voice and is always on the ceiling of the houses of the people of Sikka Regency. Given the presence of geckos on the ceiling of the house, this animal is also sacred because it is believed to be the incarnation of ancestral spirits who have magical powers. Thus, the gecko motif on the Lian Lipa is a symbol of the incarnation of ancestral spirits who have magical spiritual powers. Meanwhile, for the dragon skin motif as a symbol of the power of the universe. For the motif of bahar tibu (gold) and the top of the pineapple as a symbol of fertility, followed by the motif of plates and jars as symbols of places to store offerings. All the motifs of this ikat cloth are influenced by local beliefs or often called animism and dynamism beliefs. Thus, naming this ikat cloth was also a Portuguese tactic so that the local people at that time could accept the religious teachings that had just been spread.

Nian Nepa's or Lian Lipa's have lines from their motifs which are commonly called ikat lines. These tie lines start from ina gete, ina doi, tokang, likeng, buen to wiwir. The ina gete tie line is the dominant pattern and can be interpreted as a maternal pattern. After the ina gete, there is the ina doi tie line which is the medium line of the reduced ina gete form. Following that, the tokang tie line, which is smaller than the ina doi tie line. After that there is a lichen tie line which is smaller in size than the tokang tie line. In addition, there is an even smaller tie line which is commonly called a buen tie line. While wiwir is the edge or edge of the woven ikat cloth which is dominated by a rather wide black color. The arrangement pattern of all these tie lines must be symmetrical.
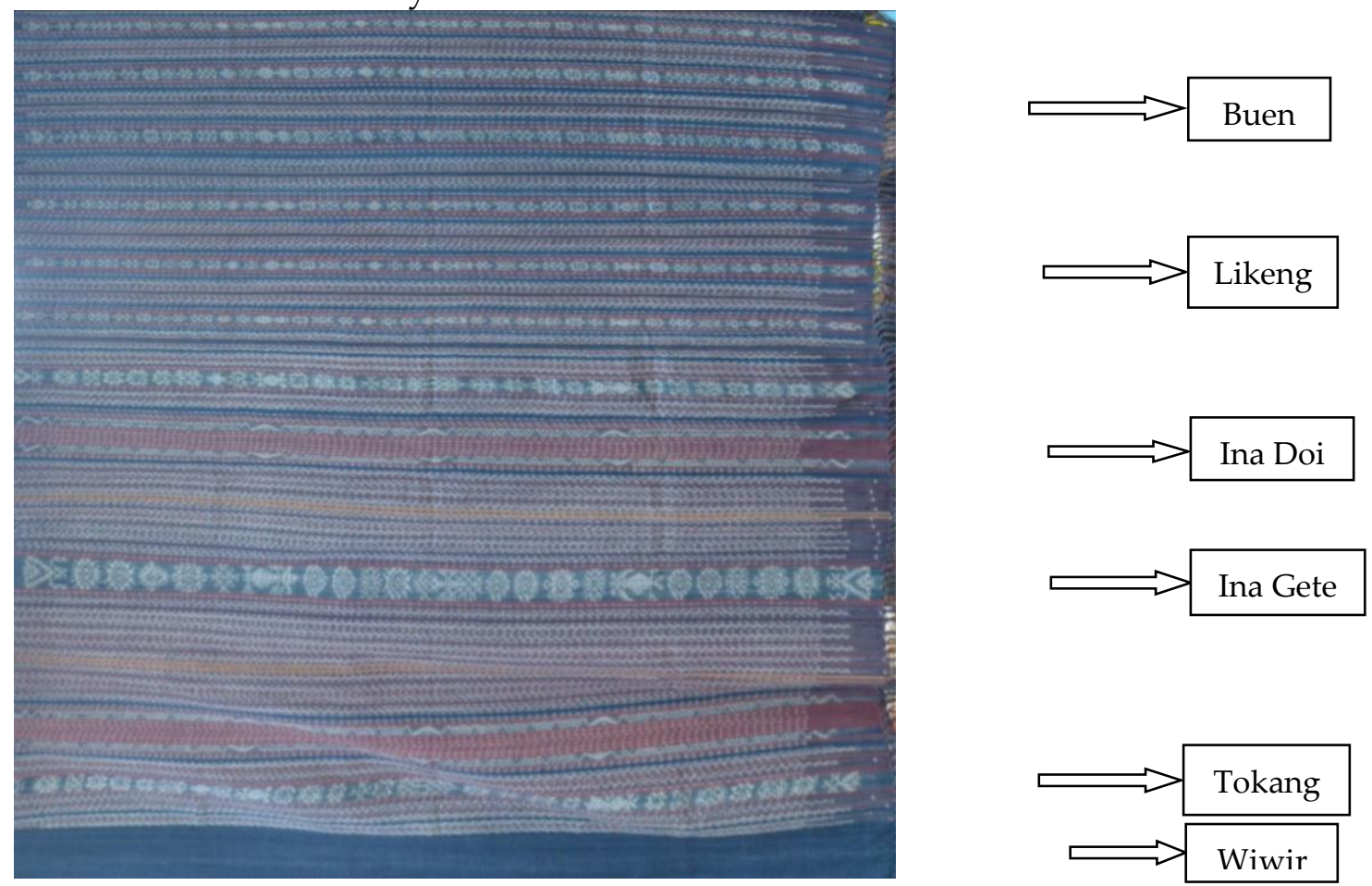

Figure 2: Tie paths from Lian Lipa or Nian Nepa

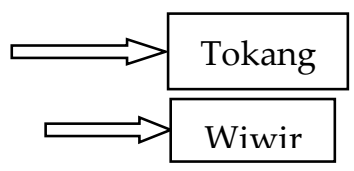

(Data Processed by Researchers, 2020) 
The motifs on this ikat cloth are located on the ina gete, tokang and likeng lanes with different sizes, ranging from large to small sizes. In the ina gete tie line, the size of the motif looks large. In the tokang tie line, the motif size looks medium and in the likeng tie line, the motif size looks very small. Meanwhile, in the ina doi tie line and the buen tie line, it is only a line scheme, dominated by maroon on the ina doi tie line and blue on the buen tie line.

The colors in the Nian Nepa or Lian Lipa utan motif are a combination of dark colors such as black and blue with light colors such as white and maroon. The black and blue colors are processed from a combination of indigo leaves mixed with whiting. The white color comes from the natural color of cotton and the red color is made from a blend of noni root bark mixed with the bark and leaves of the Iowa tree. The black and blue colors symbolize the mystery of life. That life is a mystery known only to the Creator, God Almighty. However, in the world of fashion, the dark colors in this ikat motif give a positive, formal and elegant impression. Meanwhile, the white color symbolizes a peaceful, holy and pure life. Furthermore, for the color maroon is symbolically considered a magical color favored by the soul of the sky and the soul of the earth. This is related to the materials offered to the ancestors are usually red, such as red chicken, red pig, red buffalo, red horse and red goat (Orinbao, 1992).

The Lian Lipa utans can only be worn by women who are over 50 years old. Of course, this utan is used during traditional rituals. Ages 50 years and over are biologically non-productive ages and are classified as old age who are nearing death. Thus, the black color which symbolizes the mystery of life on the woven cloth motif is interpreted as life approaching death. In addition, this utan is woven twice, so its size is 2 times longer than other woven ikat fabrics. Therefore, the way it is used is also different from other woven ikat cloth, which is folded into 2 layers, so it looks thicker.

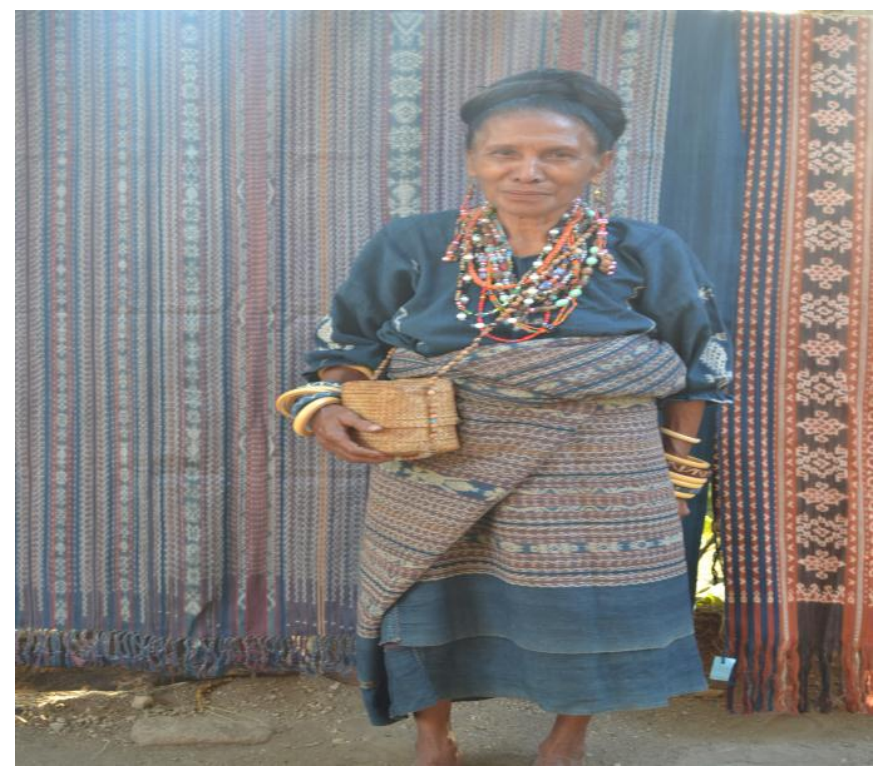

Figure 3: Utan Lian Lipa or Nian Nepa worn by Mama Yustina Neing

(Data Processed by Researchers, 2020) 
However, there is a tradition from several ethnic groups in the Sikka Regency area, specifically the Sikka-Krowe ethnicity, that the Nian Nepa or Lian Lipa for beginner weavers can only be worn or used when up to 7 pieces have been woven. The number of 7 pieces is a symbol of the strength and maturity of the weavers, that the weavers are really ready to engage in weaving activities. So, on the 8th sheet, this woven ikat cloth can already be worn or used. This tradition still survives until now and if it is violated, it will bring disaster or disaster for the weavers.

Utan Lian Lipa consists of several motifs that become a unified whole in forming its symbolic meaning. The motif of this woven ikat cloth comes from a combination of gecko animals, dragon skin, pineapple shoots and several ancient objects such as plates, jars and bahar tibu (gold).

The gecko motif on this woven cloth is the main motif and is a symbol of the incarnation of ancestral spirits who have magical powers. This departs from the presence of a gecko that is always on the ceiling of the house of the people of Sikka Regency with a rather scary physical appearance, hard skin and has a loud, booming voice. Given the presence of a gecko on the ceiling of the house with a loud booming sound, this animal is also sacred because it is believed to be the incarnation of ancestral spirits. The sacred form of this gecko which is still believed by the majority of the people of Sikka Regency, among others, geckos should not be disturbed, should not be expelled from their existence, should not be tortured, let alone killed. In addition, when the gecko is making noises at certain times, especially at night, it should not be disturbed by an answer in the form of cursing or harsh swearing. If all of this is violated, it will get bad luck, such as suffering from an unnatural illness, can also suffer an accident in the form of a motor vehicle accident and fall or be hit by trees. However, if the existence of the gecko is treated properly like a human, in this case it is the spirits of the ancestors, it will get sustenance or luck in life. For example, such as fluency in business, a healthy life free from disease outbreaks and also protected from attacks or disturbances from supernatural beings.

Even though everything seems illogical, this "myth" is still believed and believed by most of the people of Sikka Regency to this day. So, the people of Sikka Regency still believe and believe that the gecko is a symbol of the incarnation of ancestral spirits who have magical powers. Meanwhile, for the dragon skin motif as a symbol of the power of the universe. For the motif of bahar tibu (gold) and the top of the pineapple as a symbol of fertility, followed by the motif of plates and jars as symbols of places to store offerings.

In the process of social interaction, the ancestors of the people of Sikka Regency tried to communicate to each successive generation through the symbols on the ikat motifs. These future generations then interpret the symbolic meaning of the motifs on each woven ikat cloth and then direct the mindset, behavior, beliefs and customs of the people of Sikka Regency at that time based on the results of these interpretations. For example, in ancient times the people of Sikka Regency still recognized the existence of "caste" in society which of course greatly influenced the use of ikat motifs. There are woven ikat fabrics with motifs that are only appropriate 
or suitable for use by the upper middle class, but should not be used by the lower middle class. There is also a woven ikat cloth that can only be used by the lower middle class, but is not suitable for use by the upper middle class. However, as technology develops and civilization advances, caste is slowly being abandoned by the people of Sikka Regency until now. This again affects the use of the ikat cloth motif.

Therefore, based on the 3 premises of the Symbolic Interaction Theory, namely (1) humans act towards things based on the meanings that exist for them, (2) these meanings come from the process of social interaction that a person has with other people, (3) the meanings are modified and then analyzed through an interpretation process and refined during the social interaction process (Carter and Fuller, 2016), then the hermeneutics of the woven ikat (utan) Lian Lipa or Nian Nepa basically comes from 2 factors, namely the pattern of the mindset of the ancestors of the people of Sikka Regency and the process of social interaction that has taken place since ancient times until now.

The mindset of the ancestors of the people of Sikka Regency is very influential on the art of weaving, especially the decoration and motifs. Galestein and Werd (quoted in Orinbao, 1992), explain that all ikat motifs are believed to have extraordinary "magic" powers, although sometimes they make no sense. The ancestors believed that the art of weaving ikat cloth with its motifs contained a certain magical and religious power. In fact, according to Fischer (quoted in Orinbao, 1992), the influence of religio-magi is "absolute" in art, especially the art of weaving. Implicitly, it is explained that the woven ikat cloth with the motifs of step animals such as dragons, geckos, agi birds, pelicans and also ancient materials in the form of Dongson tools are religio-magi motifs that have strong spiritual meanings, both religious spirituality and magical spirituality. For the woven ikat cloth (utan) Lian Lipa or Nian Nepa, it is believed by the people of Sikka Regency to have magical power or strong magical spiritual power. Thus, it is commonly used by womens during traditional rituals and is also commonly used as a medium penolak bala during these traditional rituals.

From this mindset and process of social interaction, the motifs on each ikat cloth are then interpreted, which are then interpreted as symbolic meanings. Thus, that there was a process of social interaction from the ancient ancestors in accordance with the mindset, belief system and customs that considered humans, animals, plants and ancient objects to be sacred and sacred with high spiritual values. The ancestors believed that all motifs were wrapped in these values which contained extraordinary sacred and supernatural powers. The beliefs of the ancestors that began with the existence of this weaving art continue and are passed down by the people of Sikka Regency from every generation until now. As a result, some ethnic communities of Sikka Regency until now have become accustomed to calling these ikat motifs sacred or sacred motifs. Such as the sacred bird motif, the sacred human motif, the magic snake motif and the sacred tree motif. 


\section{E. CONCLUSION}

Ikat weaving is an aspect of culture that was inherited by the ancestors and is still very influential on society, especially the people of Sikka-NTT Regency. Departing from the mindset of the ancestors of the people of Sikka Regency and the process of social interaction that has taken place since ancient times until now, the ancestors of the people of Sikka Regency weave the Lian Lipa or Nian Nepa utan with a combination of several motifs and make the gecko the main motif. Therefore, from the results of the analysis in the form of an interpretation of the combination of several elements in the ikat cloth, it is found that the hermeneutics of the Nian Nepa or Lian Lipa are symbols of magical spiritual power from the spirits of the ancestors that can bring fortune or luck. In addition, the Lian Lipa or Nian Nepa is also a symbol of existence, the community entity of Sikka Regency, especially for womens.

\section{REFERENCES}

1. Aw, S. (2010). Komunikasi sosial budaya. Tangerang: Graha Ilmu.

2. Barker, G. G. (2016). Cross-cultural perspectives on intercultural communication competence. Journal of Intercultural Communication Research, 45(1), 13-30. https://doi.org/10.1080/17475759.2015.1104376

3. Burbank, P. M., \& Martins, D. C. (2009). Symbolic interactionism and critical perspective: Divergent or synergistic? Nursing Philosophy, 11(1), 25-41. https://doi.org/10.1111/j.1466-769X.2009.00421.x

4. Carter, M. J., \& Fuller, C. (2016). Symbols, meaning, and action: The past, present, and future of symbolic interactionism. Current Sociology, 64(6), 1-31. https://doi.org/10.1177/0011392116638396

5. Creswell, J. W. (1998). Qualitative inquiry and research design: Choosing among five traditions. London: SAGE Publications.

6. Dennis, A. (2011). Symbolic interactionism and Ethnomethodology. Symbolic Interaction, 34(3), 349-356. https://doi.org/10.1525/si.2011.34.3.349

7. Denzin, N. K. (2016). Symbolic interactionism. The International Encyclopedia of Communication Theory and Philosophy, 1-12. https://doi.org/10.1002/9781118766804.wbiect143

8. Driyanti, R. (2011). Makna simbolik tato bagi manusia Dayak dalam kajian Hermeneutika Paul Ricoeur [Universitas Indonesia]. https://doi.org/10.32528/ins.v15i2.1849

9. Edie, T. M. (2011). Tenun ikat dan songket. Pelita Hati.

10. Finlay, L. (2009). Debating Phenomenological research methods. Phenomenology $\mathcal{E}$ Practice, 3(1), 6-25. https://doi.org/10.29173/pandpr19818

11. Finlay, L. (2012). Unfolding the Phenomenological research process: Iterative stages of "Seeing Afresh." Journal of Humanistic Psychology, 53(2), 172-201. https://doi.org/10.1177/0022167812453877

12. Geertz, C. (1992). Politik kebudayaan. Jakarta: Kanisius.

13. Geertz, C. (2017). The interpretation of cultures. Hachette Book Group USA. 
14. Kafle, N. P. (2011). Hermeneutic phenomenological research method simplified. An Interdisciplinary Journal, 5(1), 181-200. https://doi.org/10.3126/bodhi.v5i1.8053

15. Kriyantono, R. (2014). Teknik praktis riset Komunikasi. Jakarta: Kencana Prenada Media Group.

16. Kuper, A. (1999). Culture: The Anthropologists' account. USA: Harvard University Press.

17. Kuswarno, E. (2009). Metode enelitian Komunikasi Fenomenologi, konsepsi, pedoman dan contoh penelitiannya. Bandung: Widya Padjadjaran.

18. Laverty, S. M. (2003). Hermeneutic Phenomenology and Phenomenology: A comparison of historical and methodological considerations. International Journal of Ualitative Methods, 2(3), 21-35. https://doi.org/10.1177/160940690300200303

19. Miles, M. B., \& Huberman, A. M. (2009). Analisis data kualitatif: Buku sumber tentang metode-metode baru. Universitas Indonesia (UI Press).

20. Mulyana, D. (2005). Ilmu Komunikasi suatu pengantar. Jakarta: Remaja Rosdakarya.

21. Mulyana, D. (2011). Komunikasi lintas budaya. Jakarta: Remaja Rosdakarya.

22. Orinbao, P. S. (1992). Seni tenun suatu segi kebudayaan orang Flores. Seminari Tinggi Santo Paulus Ledalero.

23. Samovar, L. A., Porter, R. E., \& McDaniel, E. R. (2014). Komunikasi lintas budaya: Communication between cultures (7th ed.). Salemba Humanika.

24. Subtil, F. (2014). James W. Carey's cultural approach of Communication. Intercom RBCC (Revista Brasileira de Ciências Da Comunicação), 37(1), 19-44. https://doi.org/10.1590/S1809-58442014000100002

25. Tallo, E. C. (2003). Pesona tenun Flobamora. Tim Penggerak PKK dan Dekranasda Provinsi NTT.

26. Wilson, H. S., \& Hutchinson, S. A. (1991). Triangulation of Qualitative Methods: Heideggerian Hermeneutics and Grounded Theory. Qualitative Health Research, 1(2), 263-276. https://doi.org/10.1177/104973239100100206 